\title{
Transposition
}

Musique et Sciences Sociales

Musique : patrimoine immatériel ?

\section{Champeta's Heritage: Diasporic Music and Racial Struggle in the Colombian Caribbean}

Le patrimoine de la champeta : musique diasporique et luttes raciales dans les Caraibes colombiennes

Juan D. Montoya Alzate

\section{OpenEdition}

\section{Journals}

Electronic version

URL: https://journals.openedition.org/transposition/3254

DOI: 10.4000/transposition.3254

ISSN: 2110-6134

Publisher

CRAL - Centre de recherche sur les arts et le langage

Electronic reference

Juan D. Montoya Alzate, "Champeta's Heritage: Diasporic Music and Racial Struggle in the Colombian Caribbean", Transposition [Online], 8 | 2019, Online since 15 September 2019, connection on 07 December 2022. URL: http://journals.openedition.org/transposition/3254 ; DOI: https://doi.org/ 10.4000/transposition.3254

This text was automatically generated on 17 December 2020 .

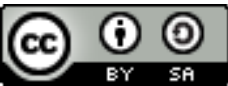

Creative Commons - Attribution-ShareAlike 4.0 International - CC BY-SA 4.0 https://creativecommons.org/licenses/by-sa/4.0/ 


\title{
Champeta's Heritage: Diasporic Music and Racial Struggle in the Colombian Caribbean
}

\author{
Le patrimoine de la champeta: musique diasporique et luttes raciales dans les \\ Caraibes colombiennes
}

Juan D. Montoya Alzate

Barranquilla's Carnival was declared an intangible "masterpiece" by UNESCO in 2003, two years after the United Nations agency started implementing the Masterpieces of the Oral and Intangible Heritage of Humanity programme. Since this first declaration, more and more Colombian actors have shown interest in inscribing practices on UNESCO's intangible heritage lists. Yuruparí healing knowledge, cowboy singing from Los Llanos and Wayú conflict-solving techniques-to name but a few manifestations performed today in Colombia-have been added to UNESCO's Representative List of Intangible Heritage. Nowadays, eight out of ten Colombian practices inscribed on UNESCO's different heritage lists are either music-based or strongly music-related. And since 2003, along with heritage entering everyday vocabularies, the Colombian State has deployed a robust legal apparatus revolving around that rather evanescent heritage. In 2006 Colombia adopted the Convention for the Safeguarding of the Intangible Cultural Heritage, two years after the convention was ratified, and in 2009 the Ministry of Culture released a set of policies on the topic. Under the title Politica de Salvaguarda del Patrimonio Cultural Inmaterial (Policy for the Safeguarding of Intangible Cultural Heritage), the national Government took the lead in regulating a field until then ruled by the Congress, the judiciary, local and regional governments, the national Constitution and international legal obligations. ${ }^{1}$ The result of these policies, mainly echoing the 2003 UNESCO Convention, has been a complex system of heritagisation that prompts governments at different levels-national, regional and local-to document and safeguard manifestations performed in their jurisdictions. Hence, practitioners may apply to have discrete expressions inscribed on one or multiple list(s). However, when champeta music leaders first engaged in the politics of heritage, they did not go 
down any of these governmental paths, choosing instead to proclaim champeta their "millenary heritage" on their own, outside of any larger framework.

2 Originating in Cartagena, champeta music has grown in popularity since the mid-1980s. It is often described as central to the crafting of popular identities and senses of belonging in Cartagena and, to a lesser extent, in the Colombian Caribbean. A vernacular reinterpretation of what was called música africana (African music) in the 1980s, champeta has been historically stigmatized and marginalized, in part due to associations with lower classes, racialized black communities and violent behaviour. As discussed below, subverting these class and racial prejudices plays a central role in the heritagisation movement. This was evident on May 2016, when leaders of this process issued a bando, a popular manifesto in which the actors established the connection between champeta music, African ancestry and Caribbean native cultures:

Public declaration of the citizens

On May $27^{\text {th }}, 2016$ at 18:00

The sociocultural manifestation

Champeta is hereby declared the Intangible Cultural Heritage

of the city of Cartagena and the historic Calamarí territories

Through bando and academy, we demand that the Colombian State and international institutions

Protect its history of liberation, resistance and popular culture

Manifested through oral tradition, nurtured by the bantú and malibú languages

Inherited from our African and Karibe indigenous ancestors in an interethnic dialogue

Uniting forces and knowledge in the name of rebellion and in favour of human dignity

Creating a popular culture of resistance and greatness amid oppression.

Champeta culture adapts itself to the times of every century; this is why it has so much to tell

As part of our history thus far made invisible. [...] (Figure 1, my translation) 


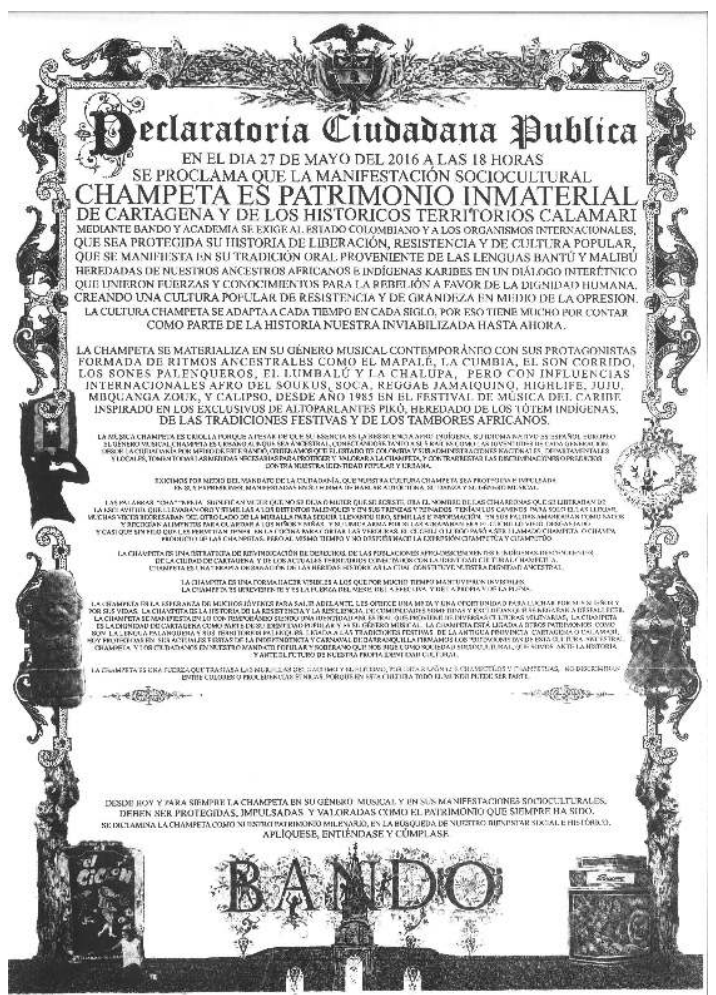

Figure 1. Bando. Handout circulating in Cartagena, Colombia. May 2016.

Nearly 800 signatures supported the bando, a document publicly displayed at La Plaza de la Aduana, where local authorities of Cartagena meet. Asomusichampeta (an association for champeta musicians) and the Roztro Foundation (a grassroots human rights NGO) had organized several political meetings where champeta practitioners had debated how this declaration could be relevant to the cultural practice, and why issuing a popular bando as an empowering performative action seemed the best way to proceed. This move aimed to undermine the alleged prerogatives of official authorities in defining what heritage is and is not, while targeting local State institutions allegedly playing a compliant role in the social processes burdening the champeta scene with racialized biases.

However, this is just a partial explanation as to why champeta practitioners (champetúos) initially opted for a popular declaration instead of pursuing the official path laid out by the State for all kinds of heritagisation processes, thus showing a profound lack of trust in Colombian institutions. This paper examines why some communities may feel excluded from the mechanisms established by the international heritage regime, by exploring how the champeta movement challenges the UNESCO paradigm. In so doing, this paper offers an overview of how the Intangible Cultural Heritage framework outlined by UNESCO in the 2003 Safeguarding Convention has been understood and put into practice in Cartagena. The local process in this Caribbean city prompts a question: does this framework aim to safeguard a specific cultural phenomenon-thus, to some extent, isolating such phenomena from their historical and social background-or can it also be used by marginal communities to gain political leverage? The following analysis argues the latter, and examines the extent to which UNESCO's heritage framework and national echoes can be appropriated as battlegrounds for social struggle. 


\section{Race in a colonial city}

The bando theatrically released on May 2016 raised several questions mainly regarding Cartagena society. Why did champetúos conclude that the popular and cultural history of champeta needed to be protected? What is the potential for rebellion in champeta music? What are the causes that unleash this rebellious spirit? Has champeta continuously adapted over the centuries, as the bando so eloquently claims? Many of these questions relate to the construction of stereotypical images of sexuality and noisiness linked to blackness in northern Colombia, while also taking into account subaltern narratives of colonial slavery. Regarding champeta, Wade points out that:

The music and its fans are generally seen as "black" and may also be seen as lowerclass, vulgar, immoral, violent, sexually licentious, and noisy, although there is little overt ethnic-racial identification with black identity as a political category, for example in the lyrics or among the fans. Yet it is clearly a music that taps into a strong sense of African diaspora. Some of its pioneering and principal exponents come from the village of Palenque de San Basilio, which in colonial times was a palenque, or community of escaped slaves that resisted colonial domination, and has retained a specific identity ever since [...] As with cumbia, the music is seen as a threat to morality and order. The fans themselves seem to revel in those images and that threat as a subversive force. They avoid identifying as Negro-in common with large segments of Cartagena's working classes-yet they are persistently identified as such. ${ }^{2}$

Racial-colonial vestiges are severe and under permanent negotiation in Cartagena. The city was one of the most important commercial ports and military outposts of the Spanish empire from the sixteenth to the early nineteenth century. In the seventeenth century, only the ports of Veracruz and Cartagena held an official permission for introducing African slaves into the so-called New World, the latter being the main depository for enslaved Africans in the areas near the Peruvian viceroyalty. Being a node in the triangular transatlantic slave trade, the city was a place mainly inhabited by black and mulatto communities by the end of the eighteenth century. ${ }^{3}$

7 Today large black communities still inhabit Cartagena and the villages nearby. According to the latest computed census, this is the Colombian city with the largest proportion of people identifying themselves as Afro-descendants. In Cartagena, 36.5\% of the general population $(319,373$ inhabitants) described themselves as negro, mulatto, Afro-Colombian or Afro-descendant. ${ }^{4}$ Also, the census statistically evidenced the disadvantaged socio-political locus of racialized populations. Afro-descendants suffer considerably higher rates of illiteracy, malnutrition, poverty and extreme poverty, in a city ranking high in the national index of unsatisfied basic needs. ${ }^{5}$ The harsh conditions associated with poverty and race, Aguilera and Meisel point out, are further intensified by stark inequality in Cartagena: the oil, shipping and tourist industries established in the city from the second half of the twentieth century have created an elite whose living conditions contrast sharply with those of people living in slums. Abril and Soto state that "centuries have passed and Cartagena is still a strongly stratified city, where social inequalities are evident especially because of the feudal behaviour of the privileged classes holding the economic and political power". ${ }^{6}$

Cartagena's tense class situation is further aggravated by veiled racial discrimination, as described by Cunin: 
A racial-hierarchical structure, the paternalist force exerted by the elite and a socio-racial arrangement are features inherited from the past, and they persist even though there have been important economic, social, political and urban transformations renovating the city, firstly at the beginning of the twentieth century and, later on, after the 1960s. ${ }^{7}$

The rebellious character that the heritagisation movement stresses to some extent conflates narratives of resistance constructed along the lines of race, class and ethnicity, in which the diasporic African element and the history of escaped slaves settling around Cartagena lay the foundation for miscellaneous accounts of historical continuity. ${ }^{8}$ For instance, the numerous prohibition attempts local authorities have deployed against sound systems in Cartagena in recent years mirror the efforts of colonial authorities to domesticate populations, allegedly following the discursive standards of Christian morality. "In 1546 and again in 1573", Bermudez recounts, "blacks were forbidden to sing, dance and play drums publicly in Cartagena and fifty years later-as they kept doing so, especially for their funerals-Jesuit Pedro Claver ordered their drums seized, held and returned only in exchange for a cash ransom". ${ }^{10}$

Present-day rebellion against racialized oppression is presented by the heritagisation movement as the continuation of rebelliousness formerly deployed against colonial oppression. The extent to which some champetúos-especially those actively involved in local politics-see continuities between their present circumstances and those of their enslaved ancestors is grounded on the little social mobility granted to racialized populations. ${ }^{11}$ This continuity is also stressed by champeta's own inception as the object of academic studies.

11 Champeta first gained scholarly attention in the early 1990s, when anthropologist Deborah Pacini produced a seminal analysis of the Colombian sound system culture that allowed the emergence of a musical scene in Cartagena, dislocating transnational exchanges responding to a centre-periphery concentric model. In Pacini's account, champeta was a form of cultural exchange multilaterally connecting peripheries, "African" and "Caribbean", in what was presented as one of the many fashions of "world music" and "world beat". According to Pacini, it is remarkable that knowledge of these diverse musical forms from the 1970s "preceded the appearance of world beat in northern contexts by at least a decade". ${ }^{12}$

12 This was possible thanks to the alternative manner of distributing music that sound systems provided from the 1950s onwards. Often described as ambulant discotheques, Colombian sound systems are popularly known as picós, a Hispanicized word that is said to refer either to traveling parties transported by pick-up trucks, or turntables and record players with the words "pick up" inscribed on their tonearms. By the 1970s, picós had become an important channel for music distribution and production in Cartagena, and the structure depended on small entrepreneurs (picoteros) competing amongst themselves to gather a large audience. At the same time, there was an increasing demand for música africana (African music) among the city's partygoers. Cartagena thus developed a market for various styles of music, from different locations, that were lumped together under the broad label of "African music".

13 Although Pacini did not clearly establish which kind of "música Africana" was popular in picós, later works have traced some of champeta's early influences. Wade and Cunin point to Kinshasa and soukous, and Wade also identifies highlife from Nigeria, konpa from Haiti, soca and reggae. ${ }^{13} \mathrm{~A}$ forerunner of champeta born in Palenque, Viviano Torres 
says the musical style was born out of chalupa from Palenque and soukous, with a bridge (espeluque) in which they combined Colombian bullerengue and South African mbaqanga. ${ }^{14}$ Aldana detects a Congolese and Nigerian connection granted by sailors in transAtlantic commercial ships: "The sailors asked DJs of the picós, ambulant discotheques, to play their music at neighbourhood parties and bars. African music became popular in the poor areas of the city that were inhabited mainly by urban and displaced blacks and mulattoes". ${ }^{15}$

Examining the political scope of champeta, one may find that from the exploration of a particular kind of "world music" connected to sound system culture, ${ }^{16}$ champeta has later been described as a "cultural phenomenon" particularly marked by categories of race and class. Afro-descendants, according to Mosquera and Provensal, find in its scene a "social and relational space" (espacio social y relacional) that allows them to identify themselves. ${ }^{17}$ Bohorquez later stressed its potential as a form of resistance, ${ }^{18}$ and Aldana proposed to take it as a "powerful cultural / political movement"-capable of "subversion of official and exclusionary channels of artistic creation". ${ }^{19}$ Scholarly champeta has been described as a peripheral world music scene, an identity under construction, a political movement and, recently, a cultural "heritage" that should be passed on to following generations. ${ }^{20}$ The current process of heritagisation may be seen as the crystallization of these and other discursive flows, constantly interacting and redefining the scopes of champeta, its localities and aims.

A question yet to be answered has to do with the economic impacts that a UNESCO declaration would have on the social practices of champeta. Historically boosted by an informal economy, circulating in an unregulated market, it is expected that the heritagisation process would impact the networks of exchange, its aesthetics, the social structures and infrastructural gaps it has forged. These are the elements adding value to sounds, objects and devices that make champeta a "performative aestheticisation of an economic system" in which social prestige and technophilia outweigh profit. ${ }^{21}$

In other words, the recent heritage stage of champeta may configure the beginning of a particular phase of commercialization and cultural appropriation beyond the Colombian Caribbean. Even though scholars have stressed the difficulties of such appropriation at the national level or in world music markets-mainly due to champeta's emphasis on sound system culture and the fierce competition for record exclusivity among picoteros-this would not be the first time different interests have blended, in the aim of making champeta a more palatable and popular music style.

Cunin argues that champeta was labelled terapia in the eighties, seeking to appeal to a whiter audience. "What is changing from African music to champeta, from champeta to terapia, is not only the music but actually its social status [...]. Its socially convenient locus implies a definition of a paler and paler 'black' subject". ${ }^{22}$ This whitening progression mirrors a similar trend followed by cumbia in the forties, when the now quintessential music of Colombian identity was considered a threat to morals and order. These articulations have been largely analysed by Wade, whose work shows the extent to which the racial configuration of Colombian nationality has been historically constructed to the detriment of cultural expressions associated with blackness. ${ }^{23}$

18 In the early noughties, Sony distributed two albums that were to introduce champeta in national mainstream channels (La champeta se tomó a Colombia and Champeta para el mundo). Ever since, the most formal champeta industry, mostly managed by picoteros, has faced the particular atomisation typical of internet and streaming platforms by 
rebranding the genre as champeta urbana-a move designed to take a slice of the colossal international success of reguetón and, to a minor extent, dancehall. ${ }^{24}$ At the same time, several independent artists have created "a more transnational blend of champeta music with electronic dance beats and world music allure". ${ }^{25}$

Both academically and popularly, champeta has been a music style strongly linked to constructions of African ancestry in the Colombian Caribbean, a characteristic that has proved decisive in formulating an Afro-political agenda at a national level. This connection was created regionally by notions and prejudices around blackness-as informed by musicians and migrants from San Basilio de Palenque-and transnationally, by the popularization of soukous and other música Africana, sometimes also known as champeta africana. "Champeta is our heritage and Palenque is a little corner of Africa in Colombia. Our aim is to interpret our ancestors' legacy", explains Viviano Torres, a pioneer of champeta and key leader in the heritagisation process. ${ }^{27}$

\section{Notions of the valuable}

Cartagena has been a key player in the national dissemination and appropriation of "heritage" jargon in Colombia. Before even discussing "intangible heritage" as such, the colonial port, fortress and monument hub of Cartagena emerged as paradigmatic for all other tangible heritage sites to be part of the World Heritage List. In 1984, the fortifications of Cartagena became the first Colombian site listed in the UNESCO tangible heritage catalogue.

This Caribbean landmark was a perfect fit for the monumental notion of heritage put forward by the 1972 World Heritage Convention. Yet inscribing the city's urban planning on the World Heritage List shaped an archetypical case that drew sharp criticism. The static view of human creativity, the disconnection between artefacts and practitioners, the over-representation of Europe's tangible heritage in the World Heritage List, the material-centric and elitist nature of the World Convention were all issues paving the way for the political boost of the intangible heritage framework. Most of these issues permeated Cartagena's case.$^{28}$ The fact that Cartagena's urban and military planning is so enmeshed in colonial history in general, and slave trading in particular, did not go unnoticed. Rafael Escallón, leader of the champeta movement, remarks:

UNESCO has a great deal of importance in Cartagena because you constantly hear the city, being an architectural masterpiece, is a heritage of mankind. Back then the [Unesco World Heritage] declaration really hurt us, because it gave value to the physical city and overlooked the cultural resistance, the multiple traditions, and the traces of Indigenous languages. Cartagena was cheered for its beauty and because visitors can still believe it is immersed in colonial times [...]. Actually the declaration was followed by sheer gentrification that expelled indigenous communities and Afros from the old city. You could hear people saying Cartagena was only the fancy and touristic walled city and we felt like we were non-existent. Even today champetúos are reluctant to go to the old city because they feel that is like going back to the place they were once kicked out of. ${ }^{29}$

In Winter's view, this monumental notion was simply ill-equipped to deal with the more pressing issues that heritage is entangled with today, such as "poverty reduction, climate change, sustainability, human rights, democracy, the future of the state and of course the protection and preservation of cultural heritage itself". ${ }^{30}$ Escallón recalls 
that material heritage was a concept familiar to Cartageneros, but Intangible Heritage was not: "I started to work with heritage in 1997, but we did not call it heritage (patrimonio) simply because we did not know we could call it that. Heritage was something finance related. We used to say music was our cultural treasure". ${ }^{31}$

Non-tangible UNESCO declarations also informed popular notions of heritage in the Colombian Caribbean. In 2005, two years after the inscription of Barranquilla's Carnival, UNESCO included a second Colombian manifestation in the Masterpieces of the Oral and Intangible Heritage of Humanity programme. The inscription of the Cultural Space of Palenque de San Basilio on the list added another raison d'être for Afro-movements engaging in the politics of culture. The Cultural Space of Palenque de San Basilio, located 50 kilometres from Cartagena, drew attention in Colombian media by insisting on features such as the racial resistance of Palenque, the historically deprived condition of Afro-descendants and the worth of prolonged cultural transmission.

"Palenque de San Basilio", the UNESCO file states, "was one of the walled communities called palenques, which were founded by escaped slaves as a refuge in the seventeenth century. Of the many palenques that existed in former times, only San Basilio has survived until the present day. It developed into a unique cultural space. The Cultural Space of Palenque de San Basilio encompasses social, medical and religious practices as well as musical and oral traditions, many of which have African roots". ${ }^{32}$

It is my intention to suggest that inscribing the (tangible) monuments of Cartagena, Barranquilla's (intangible) carnival and Palenque's (intangible) sociality on UNESCO's heritage list weaved a constellation of "masterpieces" that prompted large groups to strive for their political expectations to be fulfilled within the framework defined by UNESCO and the Colombian State, as one of its State Parties. This created a space for enormous visibility and elusive empowerment. Popular theorizations of folklore, heritage and tradition-although not interchangeable-often led to a need for enunciating social demands, an urgency for making performative culture visible and therefore politically weighty.

It is in this context of political articulation that the movement's leaders have positioned their struggle, finding in the legal apparatus of heritage renewed grounds for making popular artistic practices visible. This struggle has not diminished other instrumental tactics. That is why, after declaring champeta "heritage" through the aforementioned popular bando, the leaders of the movement also pursued the inscription of champeta on the local list of Intangible Heritage, for which they had to promote the formation of a local committee on the matter that was inexistent before 2017. In keeping with national policy, this local intangible heritage system had to be led by the local Government of Cartagena, an institution that had thus far focused solely on monumental tangible heritage.

\section{Contesting and embracing the national}

27 Heritage and multiculturalism are two pervasive and intertwined discursive formations informing large-scale cultural policies in Colombia. The latter was born out of a constitutional change aimed at safeguarding ethno-diversity. Under the multiculturalist Constitution of 1991, performing arts and music began to gain a status of hyper-relevance in the political arena. This emphasis on people's artistic practices- 
as markers of ethnic differences-would significantly inform the national Policy for the Safeguarding of Intangible Cultural Heritage, issued in 2009. And when the multicultural model cannot deliver, groups may pursue political visibility through legal frameworks such as those regulating heritage.

The multiculturalist approach is thus a political episode irreversibly marking the transformation of the politics of culture in the public arena. It comes hand in hand with a process of rewriting national constitutions that Donna Lee Van Cott calls the "fourth wave" of constitutionalism, stirred up by the fall of the Berlin Wall in 1989. ${ }^{33}$ The declaration of a "pluri-ethnic and multicultural" Colombia through the 1991 Constitution gave solid ground to a model praising diversity, a model that actually sets out to recognize such diversity as a privileged means of peace-building after decades of internal war and social upheaval. ${ }^{34}$

29 Expressive popular culture thus occupies a central place in politics today, although with this centrality come severe risks in case of failure. Indeed, as expressive cultures gained supreme relevance in the everyday negotiation of social life, national-state discourses adopted artistic practices as symbolic vehicles with the potential to mediate conflicts of all sorts. In this context, Ochoa argues, the notion of culture was transformed and expanded, in the process becoming a political and social battleground that redefined the relation between political culture and cultural policy. ${ }^{35}$

30 Key to the champeta movement is the fact that the multicultural turn brought forth promises of reversing the historically downtrodden condition of Afro-descendants, a condition worsened by racial discrimination and invisibility. ${ }^{36}$ The extent to which these promises have failed or succeeded is a question that cannot overlook a current reality marked by rampant poverty, exclusion and deprivation still hindering their socio-political agendas, but any assessment must also examine how the multicultural paradigm of the 1990s has modified former monolithic notions of symbolic nationality. If social and political struggles are to be displayed in the scenarios created by expressive culture, the multicultural model is thus to be evaluated according to its ability to outline a society in which diversity can become transformative and the most prominent struggles can be resolved.

31 Some accounts see here an opportunity for the national terrain to expand, while others identify a perilous homogenizing stratagem behind the multiculturalist model. It is my intention to suggest that the heritage processes unleashed by champeta open up the possibility of assessing whether Colombian multiculturalism promotes the fulfilment of rights in favour of vulnerable populations and the performance of cultural heterogeneity, or rather, whether the discursive uses of multiculturalism are compliant with a revitalized national homogeneity, one constructed out of ethnic differences and in a way that serves the elites.

32 According to Peter Wade's understanding of the historic national terrain, the "national" Colombian is far more multifaceted than homogenization and the prevalence of hegemonic white, mestizo, catholic and European symbolic elements. In "Music, Blackness and National Identity: Three Moments in Colombian History", Wade fiercely argued against this widespread oversimplification, describing the tremendous complexity of these constructions and disavowing various approaches that tackle the nation as a discursive device striving for complete homogenization. "Total homogeneity", he argues, "would entail the obliteration of the differences of hierarchy within the nation that even nationalist elites struggle to maintain". For him, on the 
basis of cultural difference, nationalisms discipline diversity by resignifying a heterogeneity which they actually construct. ${ }^{37}$

But scholars such as Aldana do detect a radical exclusionary operation set in motion by national elites. She expresses strong criticism of the multiculturalist paradigm, given that the 1991 constitution never implied a "multiracial definition". This partly explains the apparent dissatisfaction of champeta artists, champetúos and Palenqueros with the nation-state's multicultural approaches to cracking ethnic struggles.

The loyalty of palenquero champeta singers to their ancestral palenquero language and culture articulate for champetudos a doubly contestary site that shuns the elements emanating from dismissive high cultural principles that the local elite and the center of the nation define as civilized and legitimatize as representative of the national. ${ }^{38}$

And by situating themselves as inheritors of an "African" diasporic tradition, champeta practitioners challenge the modernist national paradigm that pins down its domains within physical boundaries and objectified identities. The transnational and diasporic scope of marginalised Afro populations is thus foregrounded. This identification practice also undermines accounts of nationality that overlook steep hierarchies, and social and ethnic differences. Aldana continues:

Within a national axiom that struggles to maintain a vision of a unified national cultural front, at the same time that it offers juridical instruments to amplify its scope, champeta resists a national reality that has historically disempowered Afrodescendants to force them to become symmetrical and to exist in a monotonic national accord. ${ }^{39}$

As seen in the "Public declaration of the citizens", champeta's most notorious spokespersons clearly state that their claims to historical justice are to be accomplished at national and even international levels. Hence, it may be rewarding to examine this process in light of two paradigms: in one, multicultural nationality still implies a palatable, domesticated, malleable, all-encompassing-though multiculturalistconfiguration of nationality, that defines and controls ethnic differences; ${ }^{40}$ and in the other, resistant and counter-hegemonic identities show no sympathy towards national and local hegemonic formations, since it understands that these formations thwart the realisation of afro agendas.

The rift, however, is permeable. Despite their initial reluctance, champetúos did end up engaging in an official heritagisation process aimed at inscribing champeta in the local, national and international lists of heritage. Since 2017 they have found themselves officially entangled in the long path of nation-state heritagisation processes that vaguely promise to end in a heritage declaration by UNESCO. This means channelling political action through the national multicultural state. In the meantime, they deny any need for validation in exogenous scenarios, by autonomously and unofficially declaring their social-artistic practice to be "heritage", something worthy of passing on. It presents itself as the continuation of Champeta's everyday cultural practices, which stress their counter-establishment nature by insisting on performing social and ethnic differences in Cartagena despite frequent attempts to ban its practices and domesticate its milieu.

This duality is also exemplified in Aldana's criticism. Severely condemning the multicultural approach, her view has its flip side in the fact that it acknowledges how such a model has also deployed ethnic identity processes shaping diverse local Afroactivisms. Hence, Aldana argues, champeta stands for paramount political potential. ${ }^{41}$ 
The heritagisation process could thus be taken as a political component stemming from this duality.

While champetúos usually stress their marginal local position, engaging in the official heritagisation process does not unequivocally amount to resisting the national multiculturalist apparatus. In doing so, they also play the game of national politics, determining what is heritage and worth passing on to next generations under the mechanisms the nation-state has established for the cultural plurality to be performatively sustained. At the same time the racial struggle has partially abandoned the multicultural (national) political arena and fled to the heritage (international) terrain. In many ways, this implies the exploitation of the heritage framework as a renewed battleground and shows to what extent the politics of multiculturalism and heritage are deeply intertwined.

What the current heritagisation process comprises is thus a re-evaluation of what the national politics of representation imply and how they operate. In doing so, it opts for the UNESCO transnational heritage model, one that applauds diversity, although it can hardly be held accountable in the safeguarding of that performative diversity.

The nation, Homi Bhabha argues, operates as a form of social amnesia. In being part of an imagined collective group, subjects in the nation are forced to let part of the past go, to somehow let traumas fade away ${ }^{42}$ To some extent, the multicultural approach implies certain (national) homogenization, but it does not automatically endorse forgetting. And champetúos' duality towards the multicultural approach and the national project may lie in the fact that they use the legal tools these models have provided whilst refusing to let go of this past marked by slavery and a caste system, hence looking at local and national power formations in discomfort. These circumstances amount to creating a typical conundrum in processes of cultural appropriation, in which practitioners reject the implicit standardization of their practices but still pursue visibility in order to gain political leverage.

41 As a point of convergence for the construction of symbolic nationality, in its articulations towards colonial history, Cartagena has been a key actor in the multicultural model. Its articulations reveal the full range of possible inconsistencies and potentialities, as well as the transformations of cultural and political practices after 27 years of constitutional history and engineered cultural policies. It is in this context that the social process unleashed by champeta becomes relevant, considering that cultural policies not only validate artistic expressions but also give validity to ways of being and living.

\section{New music, old heritage}

The action of performatively declaring champeta to be "heritage" in 2016 became an act of legitimacy-by which champetúos denied the authority of any exogenous entity-as well as a precedent for further political action.

The articulation of identity, political aims and performative art is rendered precise in the file prepared for the inscription on the local list. This application elaborated by Asomusichampeta and Roztro Foundation-the two organisations involved in the bando declaration-is currently under official discussion. The ultimate goal is for champeta to 
be inscribed on both the Colombian List of Representative Intangible Heritage and UNESCO's Representative List of the Intangible Cultural Heritage. It reads:

Achieving the inclusion of champeta on the National List of Representative Intangible Heritage would be significant because, through a safeguarding plan, it will facilitate the restoration of rights to indigenous, Afro and palenquero populations. This plan aims to give back dignity to these peoples, guaranteeing the study of artistic practices and sustaining the patrimonial identity of champeta. ${ }^{43}$ demands-nearly 4,000 people in total, according to Fundación Roztro. However, due to its unstable relation with the "national", obtaining the inscription of champeta on the UNESCO List of the Intangible Cultural Heritage of Humanity looks like a genuine challenge. This inscription will have to deal with a national policy that assesses candidacies under the criteria of "national interest". The Colombian Policy for the Safeguarding of Intangible Cultural Heritage states that the most relevant criteria for nominating a file is "a national interest for showing the practice as expression and value of national identity". ${ }^{46}$ The pressing question that UNESCO will have to discuss is whether the 2003 Convention safeguards the intangible heritage of humanity, or primarily heritage that State Parties are willing to acknowledge as such.

And whilst the struggle continues in Cartagena along the lines of the politics of heritage, champeta has gained national audiences, in part due to a music phenomenon that may be regarded as the concretion of the multicultural approach. In the early noughties, Colombian audiences were confronted with what came to be known as the "New Colombian Music". ${ }^{47}$ Following Carlos Vives' commercial success in the early and mid-1990s, national state radio, public music festivals and private media outlets fostered the distribution of diverse vernacular forms of music-usually spiced up with some jazz, electronic or rock music traits-while challenging the limits of what the 
nation allegedly encapsulates. ${ }^{48}$ As García contends, the movement seems to be "configuring new belongings and new senses of Colombianness, which are much more inclusive". ${ }^{49}$

In constructing this inclusive symbolic national terrain, performative culture has been heavily reassessed by the political paradigms discussed above, namely: constitutionalism, multiculturalism and the frameworks of Intangible Cultural Heritage drawn from the 2003 UNESCO Convention. I must emphasize that they all share the goal of relocating the overlooked social site that vernacular cultural production occupied in Colombia before the nineties.

In sum, the "national" operates through a multiculturalist language that manifests itself in the New Colombian Music phenomenon, one that has encompassed some of the musical works the more fashionable champeta artists have produced. My suggestion is that to some extent champeta has been absorbed by the movement; it has entered the realm of the national by sticking to the difference it stresses discursively, by raising its dissonant voice in a political project that theoretically praises diversity, by stressing the locality of a musical style that has proven to be diasporic and transnational from day one.

50 Champeta, Mosquera and Provensal say,

has touched the "beautiful people", the urban culture of Cartagena, making it more Caribbean, slowly undermining an elitist imaginary linking the city to colonial, walled and Hispanic culture, insufflating to the insular Caribbean the African legacy that Cartagena holds. This is why champeta is truly a silent revolution with a diffuse and non-verbal ideology. ${ }^{50}$

51 To be a part of national musical accounts, diverse vernacular musical styles in Colombia have undergone historical "whitening" processes, since the mid-twentieth century, consolidating a form of cultural appropriation that allowed black-Caribbean musical styles to play a relevant role in narrations of nationality. ${ }^{51}$ However, Aldana argues that black communities in Cartagena have historically stressed the "black" condition of champeta, abandoning "whitened" musical styles in order to solidify ethnic, racial and class differences. I would add that all of this was the rule before the dissemination of the rhetoric raised by the New Colombian Music.

This movement has reanimated folklorisms and nationalist accounts that have reassessed cultural items that may fall into the category of heritage, thus challenging the limits of the monolithic cultural nation. Champetú is an example of this resignification. Since late 2015, half champeta party and half a social movement, it has taken the genre from the sound system milieu to high profile spaces in exclusive and gentrified areas of Cartagena. Crowds of international spectators and locals of all colours mix here, where DJs and champeta singers stress the potential of these tunes as identity roadmaps for affirmative action.

Although most academic analyses done thus far conclude that champeta has remained a local scene with little resonance beyond areas near Cartagena and Barranquilla, my personal account is that champeta has managed to extend its sonic influences to the Colombian Caribbean while largely informing musical practices in the hinterlands. ${ }^{52}$ Large portions of the urban populations in Colombia are familiar with and sympathetic towards champeta, even though its afro and diasporic history is hardly narrated beyond the Colombian Caribbean and its sound system culture remains mostly disseminated in popular neighbourhoods of Cartagena and Barranquilla. 
54 Anyone interested in this phenomenon may look into the national echoes and trajectories of artists such as Charles King, Kevin Florez, Mr. Black, La Universidad de la Champeta, Tribu Baharú, Bomba Estéreo, Big Deivis, Bazurto All Stars, Systema Solar or La Mákina del Karibe. Although most of these artists produce independently, many are in fact part of the mainstream in public national radio and digital channels.

55 Although often fighting marginalisation in Cartagena, champeta's apparent inscription in a rather inclusive national repertoire has granted it legitimacy, intercultural dialogue and national resonance. Meanwhile, it seems some of its traits have been culturally appropriated and to some extent "whitened", although the mainstreaming processes seem less commercially successful at the national level than those making vallenato or tropipop appealing to middle-class audiences. ${ }^{53}$

It is clear that the commercial and political spheres are intertwined. Again, the partial success of some of the above-mentioned artists may be explained by the multicultural turn. On the $18^{\text {th }}$ of February 2016, for instance, champeta gained relevance in academic circles of the national capital thanks to an event hosted by Universidad de los Andes, a private institution widely considered the higher education centre of the national elite. The event offered a short lecture followed by a concert with champeta pioneers Charles King, Viviano Torres and Louis Towers. That day, among the national cream of the crop, the event's promoters repeatedly emphasized that champeta was getting its academic diploma. It was champeta's graduation day, so to speak. ${ }^{54}$

It is hard to imagine these transformative scenarios being possible without the national process of identity formation unleashed by multiculturalism. Moreover, in promoting the planning of safeguarding measures, the UNESCO model has prompted the selfassessment and self-definition of the champeta community. Heritagisation processes of this sort are often mingled with social and political issues beyond the safeguarding perspective itself, as the Colombian Government is not only fully aware, but actually has directed the application of the UNESCO Intangible Heritage Convention. ${ }^{55}$

The heritagisation process that champeta practitioners have undertaken deals in paradigmatic ways with national and international paradigms of socio-political vindication, of negotiating social difference and political participation. Racial struggles are made visible through this progression of events, as they become a challenge for representations of the nation, and therefore become a challenge for different conservative accounts regarding heritage. In the meantime, champeta leaders genuinely seek transnational mirrors, dialogues among actors familiar with the diasporic condition brought about by colonial slavery.

What this heritagisation process reveals is the enhanced social dimension of champeta: first, because there is a current local debate in Cartagena about whether or not a popular, sound system-based kind of music, usually associated with deprived and black neighbourhoods, should or could be considered heritage; second, because there is the performative appropriation of spaces and soundscapes by champetúos in Cartagena, which render them visible ${ }^{56}$; and third, because there is a relevant re-signification of "African" sounds, raising awareness about the racial bias still operating in the context of the stratified Caribbean. The destiny of this process, yet to be decided, will speak volumes not only about this contested music style, but particularly about all the deep social cracks that intangible champeta makes almost tangible. 


\section{BIBLIOGRAPHY}

ABRIL Carmen and sото Mauricio, Entre la champeta y la pared: el futuro económico y cultural de la industria discográfica en Cartagena, Bogota, Sistema Nacional de Información Cultural / Unidad Editorial del Observatorio del Caribe Colombiano, 2004.

AGUILERA María and MEISEL Adolfo, ¿La Isla que se Repite? Cartagena en el censo de población de 2005, Banco de la República / Centro de Estudios Regionales (CEER), Documentos de trabajo sobre economía regional, no. 109, 2009.

ALDANA Ligia, "Blackness, Music and (National / Diasporic) Identity in the Colombian Caribbean", VALDÉs Vanessa Kimberly (ed.), Let Spirit Speak!: Cultural Journey Through the African Diaspora, Albany, State University of New York Press, 2012, p. 39-50.

ALDANA Ligia, "Policing Culture: The Champeta Movement under the New Colombian Constitution", International Journal of Cultural Policy, vol. 14, no. 3, 2008, p. 265-280.

ALDANA Ligia, "Somos Afro: Champeta Music as a Means for Cultural/(Political) Organization for Afrodescendants in Colombia", Callaloo, vol. 36, no. 2, 2013, p. 391-402.

BERMÚDEZ Egberto, “Towards a History of Colombian Music”, Farnsworth-Alvear Ann, Palacios Marco and Gómez López Ana María (eds.), The Colombian Reader: History, Culture, Politics, London, Duke University Press, 2017, p. 75-83.

BHABHA Homi, The Location of Culture, London, Routledge Classics, 2004.

BIREMBAUM QUINTERo Michael, “Acerca de una estética popular en la música y cultura de la champeta”, Asociación de Colombianistas (ed.), Colombia y el Caribe, XIII congreso de colombianistas, ${ }^{\text {Barranquilla, Universidad del Norte, 2005, p. } 202-215}$

BIRENBAUM Michael, "Exchange, Materiality and Aesthetics in Colombian Champeta", Ethnomusicology Forum, vol. 27, no. 1, 2018, p. 3-24.

BOHÓRQUEZ Leonardo, "La champeta en Cartagena de Indias: terapia musical popular de una resistencia cultural”, Memorias del congreso latinoamericano de músicas populares, 2000.

CUNIN Elizabeth, "Cartagena y el Caribe: razones y efectos actuales de una identificación", En torno a las Antillas Hispánicas: ensayos en homenaje al Profesor Paul Estrade, Archivo Histórico Insular de Fuerteventura, 2004, p. 371-382.

CUNIN Elizabeth, “De Kinshasa a Cartagena, pasando por París: itinerarios de una 'música negra': la champeta", Aguaita, no. 15-16, December 2006, p. 176-192.

CUNIN Elizabeth, Identidades a flor de piel, Bogotá, Uniandes / Observatorio del Caribe Colombiano, 2003.

ELÍAS Jorge Enrique and VIDAL Antonino, "La desmemoria impuesta a los hombres que trajeron. Cartagena de Indias en el siglo XVI y XVII: un depósito de esclavos”, Cuadernos de historia, no. 37, December 2012, p. 7-31.

GARCíA David, "The Case of Chocquibtown: Approaches to the Nation in Contemporary New Colombian Music", FANTA Andrea, HERRERO-OLAIZOLA Alejandro, and RUTTER-JENSEN Chloe (eds.), Territories of Conflict: Traversing Colombia through Cultural Studies, Rochester, University of Rochester Press, 2017, p. 221-230. 
GIOLITTO Loredana, "Esclavitud y libertad en Cartagena de Indias: reflexiones en torno a un caso de manumisión a finales del periodo colonial”, Fronteras de la historia, vol. 8, 2003, p. 65-92.

GIRALDO Jorge and VEGA Jair, "Entre champeta y sonidos africanos: fronteras difusas y discusiones sobre 'músicas negras' en el Caribe colombiano”, Memorias, no. 23, 2014, http://

rcientificas.uninorte.edu.co/index.php/memorias/article/viewArticle/6214/6368, accessed July $23^{\text {rd, }}$ 2019.

GUTIÉRREZ Ildefonso, Historia del negro en Colombia: ¿sumision o rebeldia?, Bogotá, Editorial Nueva América, 1986.

HERNÁNDEZ Oscar, "Colonialidad y poscolonialidad musical en colombia”, Latin American Music Review / Revista de música latinoamericana, vol. 28, no. 2, 2007, p. 242-270.

Ministerio de Cultura de Colombia, "Política de salvaguarda del patrimonio inmaterial", Convención y política de salvaguardia del PCI, Bogotá, Ministerio de Cultura, 2011, p. 35-92.

MONTOYA Juan, Champeta and Intangible Cultural Heritage, Leuven, KU Leuven, MA thesis, 2015.

MONTOYA Juan, Champeta: la 'nueva' música africana del Caribe, Medellín, Asociación de Colombianistas, 2015, http://www.colombianistas.org/Portals/0/Congresos/XIXPonencias/ Montoya\%20Alzate_Juan\%20D_ponencia.pdf, accessed June 7th, 2018.

MOSQUERA Claudia and PRovenSAL Marion, "Construcción de identidad caribeña y popular en Cartagena de Indias a través de la música y el baile de champeta", Aguaita, no. 3, 2000, p. 98-114.

MÜLLER Viola, “Champeta Music: Between Regional Popularity and National Rejection: Colombia 1970-2000", Canadian Journal of Latin American and Caribbean Studies / Revue canadienne des études latino-américaines et caraibes, vol. 43, no. 1, p. 79-101.

MÚNERA Alfonso, El fracaso de la nación: región, clase y raza en el caribe colombiano (1717-1821), Bogotá, Banco de la República / El Áncora Editores, 1998.

MUNJERI Dawson, “Tangible and Intangible Heritage: From Difference to Convergence”, Museum International, vol. 56, no. 1-2, p. 12-20.

MURPHY Michael, Multiculturalism: a Critical Introduction, New York, Routledge, 2012.

NAVARRETE María Cristina, Génesis y desarrollo de la esclavitud en Colombia: siglos XVI y XVII, Cali, Universidad del Valle, 2005.

осноA Ana María, “Disencounters Between Music's Allure and the Expediency of Culture in Colombia", Latin American Research Review, vol. 48, 2013, p. 12-29.

осHOA Ana María, Entre los deseos y los derechos: un ensayo crítico sobre políticas culturales, Bogotá, Colección Ensayo Crítico ICANH, 2003.

PACINI Deborah, “The Picó Phenómenon in Cartagena, Colombia”, América Negra, no. 6, Bogotá, Pontificia Universidad Javeriana, 1993, p. 69-115.

PNUD, Los Afrocolombianos frente a los objetivos de desarrollo del milenio, Bogotá, PNUD, 2011, http:// www.undp.org/content/dam/colombia/docs/ODM/undp-co-odmafrocolombianos-2012.pdf, accessed October 28th, 2018.

SANTAMARÍA Carolina, “La 'Nueva Música Colombiana': la redefinición de lo nacional en épocas de la world music”, El artista, no. 4, 2007, p. 6-24.

SANZ Maria Alejandra, Fiesta de picó, Bogotá, Universidad del Rosario, 2011. 
SEVILlA Manuel, ochOA Juan Sebastián, SANTAMARÍA Carolina, and CATAÑo ARANGo Carlos Eduardo (eds.), Travesías por la tierra del olvido: modernidad y colombianidad en la música de Carlos Vives y La Provincia, Bogotá, Editorial Pontificia Universidad Javeriana, 2014.

STREICKER Joel, "Policing Boundaries: Race, Class, and Gender in Cartagena, Colombia”, American Ethnologist, vol. 22, no. 1, 1995, p. 54-74.

UNESCO, "Cultural Space of Palenque de San Basilio", https://ich.unesco.org/en/RL/culturalspace-of-palenque-de-san-basilio-00102, accessed October 28th, 2018.

VAN COTT Donna Lee, The Friendly Liquidation of the Past: The Politics of Diversity in Latin America, Pittsburgh, University of Pittsburgh Press, 2000.

WADE Peter, "African Diaspora and Colombian Popular Music in the Twentieth Century", Black Music Research Journal, vol. 28, no. 2, 2008, p. 41-56.

WADE Peter, "Music, Blackness and National Identity: Three Moments in Colombian History", Popular Music, vol. 17, no. 1, 1998, p. 1-19.

WADE Peter, Música, raza y nación, Bogotá, Vicepresidencia de la República, 2002.

WINTER Tim, "Clarifying the Critical in Critical Heritage Studies", International Journal of Heritage Studies, vol. 19, no. 6, 2012, p. 532-545.

ŽIžEK Slavoj, "Multiculturalism, Or, the Cultural Logic of Multinational Capitalism”, New Left Review, no. 225, 1997, p. 28-51.

\section{NOTES}

1. Ministerio de Cultura de Colombia, "Política de salvaguarda del patrimonio inmaterial", Convención y política de salvaguardia del PCI, Bogotá, Ministerio de Cultura, 2011, p. 35-92.

2. WADE Peter, "African Diaspora and Colombian Popular Music in the Twentieth Century", Black Music Research Journal, vol. 28, no. 2, 2008, p. 51.

3. On colonial slavery in Cartagena, see ELÍAS Jorge Enrique and VIDAL Antonino, "La desmemoria impuesta a los hombres que trajeron. Cartagena de Indias en el siglo XVI y XVII: un depósito de esclavos", Cuadernos de historia, no. 37, December 2012, p. 7-31; GIOLITTo Loredana, "Esclavitud y libertad en Cartagena de Indias: reflexiones en torno a un caso de manumisión a finales del periodo colonial", Fronteras de la historia, vol. 8, 2003; MÚNERA Alfonso, El fracaso de la nación: región, clase y raza en el caribe colombiano (1717-1821), Bogotá, Banco de la República / El Áncora Editores, 1998, p. 77-78; NAVARRETE María Cristina, Génesis y desarrollo de la esclavitud en Colombia: siglos XVI y XVII, Cali, Universidad del Valle, 2005.

4. Dane-Univalle, Análisis regional de los principales indicadores sociodemográficos de la comunidad afrocolombiana e indígena a partir de la información del censo general 2005, p. 64 (dane.gov.co/files/ censo2005/etnia/sys/Afro_indicadores_sociodemograficos_censo2005.pdf, accessed Nov 1, 2018).

5. This index measures multidimensional poverty and takes into account needs such as proper housing, proper water and sewer services, basic household income and school attendance in youngsters. The national census showed that $26.2 \%$ of the population in Cartagena does not satisfy one or more of these basic needs. The analysis of Aguilera and Meisel exclusively focuses on the most populated cities, of which Cartagena ranks sixth. AGUILERA María and MEISEL Adolfo, ¿La Isla que se Repite? Cartagena en el censo de población de 2005, , Banco de la República / Centro de Estudios Regionales (CEER), Documentos de trabajo sobre economía regional, no. 109, 2009, p. 37. See also PNUD, Los 
Afrocolombianos frente a los objetivos de desarrollo del milenio, Bogotá, PNUD, 2011 (undp.org/content/dam/colombia/docs/ODM/undp-co-odmafrocolombianos-2012.pdf, accessed October 28, 2018).

6. ABRIL Carmen and sОто Mauricio, Entre la champeta y la pared: el futuro económico y cultural de la industria discográfica en Cartagena, Bogota, Sistema Nacional de Información Cultural / Unidad Editorial del Observatorio del Caribe Colombiano, 2004, p. 13.

7. cunIN Elizabeth, Identidades a flor de piel, Bogotá, Uniandes / Observatorio del Caribe Colombiano, 2003, p. 146 (my translation): "Una estructura racial jerarquizada, el paternalismo ejercido por la elite y una organización socio-racial son características heredadas del pasado, persisten pese a las considerables transformaciones económicas, sociales, políticas y urbanas que, primero a comienzos del siglo XX y desde la década de los sesenta después, han renovado la ciudad".

8. BIREMBAUM QUiNTERo Michael, "Acerca de una estética popular en la música y cultura de la champeta", Asociación de Colombianistas (ed.), Colombia y el Caribe, XIII congreso de colombianistas, Barranquilla, Universidad del Norte, 2005, p. 204.

9. On sound systems bans, see SAnz Maria Alejandra, Fiesta de picó, Bogotá, Universidad del Rosario, 2011, chapter IV.

10. BERMÚDEZ Egberto, "Towards a History of Colombian Music", FARNSWORTH-ALVEAR Ann, PALACIOS Marco and Gómez LóPez Ana María (eds.), The Colombian Reader: History, Culture, Politics, London, Duke University Press, 2017, p. 78.

11. STREICKER Joel, "Policing Boundaries: Race, Class, and Gender in Cartagena, Colombia", American Ethnologist, vol. 22, no. 1, 1995, p. 54-74.

12. PAciNi Deborah, "The Picó Phenómenon in Cartagena, Colombia", América Negra, no. 6, Bogotá, Pontificia Universidad Javeriana, 1993, p. 70.

13. CUNIN Elizabeth, "De Kinshasa a Cartagena, pasando por París: itinerarios de una 'música negra': la champeta”, Aguaita, no. 15-16, December 2006, p. 176-192.

14. Universidad de los Andes, "Los creadores de la champeta", Bogotá, Universidad de los Andes, 2016, 03:15 (https://www.youtube.com/watch?v=n-fc1ir2lAM, accessed June 6, 2018).

15. ALDANA Ligia, "Blackness, Music and (National / Diasporic) Identity in the Colombian Caribbean", Let Spirit Speak!: Cultural Journey Through the African Diaspora, VALDÉs Vanessa Kimberly (ed.), Albany, State University of New York Press, 2012, p. 41.

16. PACINI, "The Picó Phenómenon".

17. MOSQUERA Claudia and PROVENSAL Marion, "Construcción de identidad caribeña y popular en Cartagena de Indias a través de la música y el baile de champeta”, Aguaita, no. 3, 2000, p. 21.

18. вонó́RQUEZ Leonardo, "La champeta en Cartagena de Indias: terapia musical popular de una resistencia cultural", Memorias del congreso latinoamericano de músicas populares, 2000.

19. ALDANA Ligia, "Somos Afro: Champeta Music as a Means for Cultural/(Political) Organization for Afrodescendants in Colombia", Callaloo, vol. 36, no. 2, 2013, p. 392.

20. моNтоYA, Juan, Champeta: la 'nueva' música africana del Caribe, Medellín, Asociación de Colombianistas, 2015 (docplayer.es/33939114-Medellin-miercoles-1-de-julio-de-champeta-lanueva-musica-africana-del-caribe-juan-d-montoya-alzate.html, accessed August 20, 2019).

21. BIREnBAUM Michael, "Exchange, Materiality and Aesthetics in Colombian Champeta", Ethnomusicology Forum, vol. 27, no. 1, 2018, p. 10.

22. cunin Elizabeth, "Cartagena y el Caribe: razones y efectos actuales de una identificación", En torno a las Antillas Hispánicas: ensayos en homenaje al Profesor Paul Estrade, 2004, p. 378 and 380 (my translation): "[...] estas variaciones semánticas no son neutrales. Porque lo que está cambiando, de la música africana a la champeta y de la champeta a la terapia, no es solamente la música sino más bien su estatuto social. [...] su carácter socialmente conveniente se acompaña de la definición de un 'negro' cada vez más pálido".

23. WADE Peter, Música, raza y nación, Bogotá, Vicepresidencia de la República, 2002. 
24. For an assessment of champeta urbana, see MÜLLER Viola, "Champeta Music: Between Regional Popularity and National Rejection: Colombia 1970-2000", Canadian Journal of Latin American and Caribbean Studies / Revue canadienne des études latino-américaines et caraibes, vol. 43, no. 1, p. 96.

25. оснод Ana María, "Disencounters Between Music's Allure and the Expediency of Culture in Colombia”, Latin American Research Review, vol. 48, 2013, p. 27.

26. See cUnIN, "Cartagena y el Caribe: razones y efectos actuales de una identificación"; and cuNIN, "De Kinshasa a Cartagena", p. 176-192.

27. Personal interview, February $20^{\text {th }}, 2016$ (my translation): "Esa es una herencia. Palenque es un rincón de África en Colombia. Nosotros buscamos tomar una herencia de nuestros antepasados, con ese legado histórico que han dejado".

28. MUNJERI Dawson, "Tangible and Intangible Heritage: From Difference to Convergence", Museum International, vol. 56, no. 1-2.

29. Whatsapp interview, March $25^{\text {th }}, 2018$ (my translation): “En Cartagena nos pesa mucho la UNESCO porque se la pasan nombrando, ya que Cartagena misma es patrimonio de la humanidad como joya arquitectónica y no sé qué cosa. Eso nos dio muy duro, cuando de la ciudad de Cartagena valoraron no la resistencia y cultura, ni las tradiciones, ni los vestigios de nuestra lengua, sino que valoraron lo bonita que es y cómo se parece a la colonia. Eso en vez de empoderarnos nos dolió [...]. Hubo un proceso de gentrificación y la mayoría de los indígenas y afro que todavía perduraban en el centro fueron sacados a los extramuros. Comenzaron a decir que Cartagena era el 'corralito de piedra', cosas que nos hacía sentir como que no existíamos. Tanto es así que todavía hay una resistencia a hacer actividades en el centro por parte de los champetúos, porque ellos consideran que es regresar al lugar de donde fueron expulsados".

30. WINTER Tim, "Clarifying the Critical in Critical Heritage Studies", International Journal of Heritage Studies, vol. 19, no. 6, 2012, p. 542.

31. Whatsapp interview, March $25^{\text {th }}, 2018$ (my translation): "Cuando yo comencé con el tema del patrimonio fue en el año de 1997, pero yo no le llamaba patrimonio porque no teníamos conciencia de que eso se llamaba así. Para nosotros patrimonio era una cosa de tener dinero, era un patrimonio económico. Decíamos que era nuestro tesoro cultural".

32. UNESCO, "Cultural Space of Palenque de San Basilio" ( ich.unesco.org/en/RL/cultural-space-of-palenque-de-san-basilio-00102 , accessed October 28, 2018).

33. van COTT Donna Lee, The Friendly Liquidation of the Past: The Politics of Diversity in Latin America, Pittsburgh, University of Pittsburgh Press, 2000.

34. осHOA Ana María, Entre los deseos y los derechos: un ensayo crítico sobre políticas culturales, Bogotá, Colección Ensayo Crítico ICANH, 2003, p. 18 and 24.

35. Ibid.

36. Scholar Nina S. de Friedemann's pivotal work emphasizes the historical invisibility of Afropopulations. See CUNIN, Identidades a flor de piel, p. 27; also GUTIÉRREZ Ildefonso, Historia del negro en Colombia: ¿sumision o rebeldia?, Bogotá, Editorial Nueva América, 1986.

37. WADE Peter, "Music, Blackness and National Identity: Three Moments in Colombian History", Popular Music, vol. 17, no. 1, 1998, p. 2.

38. ALDANA Ligia, "Policing Culture: The Champeta Movement under the New Colombian Constitution", International Journal of Cultural Policy, vol. 14, no. 3, 2008, p. 274.

39. ALDANA, "Somos Afro", p. 394.

40. For a sharp critique on multiculturalism and commodification, see žİžEK Slavoj, "Multiculturalism, Or, the Cultural Logic of Multinational Capitalism", New Left Review, no. 225, 1997. See also MURPHY Michael, Multiculturalism: a Critical Introduction, New York, Routledge, 2012, p. 6: "multiculturalism advocates policies which seek to accommodate the different identities, values and practices of both dominant and non-dominant cultural groups in culturally diverse society". 
41. ALDANA, "Somos Afro", p. 392.

42. BHABHA Homi, The Location of Culture, London, Routledge Classics, 2004, p. 230.

43. Fundación Roztro, Champeta patrimonio inmaterial: reconocimiento de la cultura popular como estrategia de reivindicación de derechos humanos en Cartgaena, July $12^{\text {th }}, 2017$, p. 10 (my translation): "La inclusión de la manifestación Champeta en la Lista Representativa de Patrimonio Cultural Inmaterial de ámbito nacional es importante porque permitirá, la reivindicación de los derechos de las poblaciones afro, raizales y palenqueas, indígenas y caribeños, dentro de un plan de salvaguardia que permitirá la dignificación y continuidad de los estudios y puestas en escenas, de la identidad patrimonial Champeta". (Sic.)

44. "Champeta es patrimonio de la cultura popular", eltiempo.com, April 24, 2007 (eltiempo.com/archivo/documento/CMS-3525878, accessed April 19, 2018).

45. Cartagena's Intangible Heritage Committee, Meeting on June $29^{\text {th }}, 2016$ (my translation): "Nosotros estamos buscando cómo hacerles entender a los administradores de esta ciudad que la champeta tiene una forma de bailar, una forma de decir las cosas, una forma de vestir, una forma de transmitir y exteriorizar los sentimientos de nuestros pobladores. Con el patrimonio buscamos que aprendan a entender la dimensión que esto tiene. Si ellos entran a profundizar en lo que hay aquí, tendríamos la posibilidad de volver esto una fortaleza para el turismo que ellos manejan".

46. Ministerio de Cultura de Colombia, "Política de salvaguarda del patrimonio inmaterial", p. 86 (my translation): "Debe existir un interés nacional por mostrar ante el mundo la manifestación, como expresión y valor de la identidad nacional".

47. SANTAMARÍA Carolina, "La 'Nueva Música Colombiana': la redefinición de lo nacional en épocas de la world music", El artista, no. 4, 2007, p. 6-24.

48. SEVILlA Manuel, ochOA Juan Sebastián, SANTAMARÍA Carolina, and CATAÑo ARANGo Carlos Eduardo (eds.), Travesías por la tierra del olvido: modernidad y colombianidad en la música de Carlos Vives y La Provincia, Bogotá, Editorial Pontificia Universidad Javeriana, 2014.

49. GARCía David, "The Case of Chocquibtown: Approaches to the Nation in Contemporary New Colombian Music", FANTA Andrea, HERRERo-olaizola Alejandro, and RUTTER-JENSEN Chloe (eds.), Territories of Conflict: Traversing Colombia through Cultural Studies, Rochester, University of Rochester Press, 2017, p. 228.

50. MOSQUERA and PROVENSAL, "Construcción de identidad caribeña", p. 22-23 (my translation): "Poco a poco ha ido impregnando a la gente 'bien', a la cultura de la ciudad transformándola volviéndola más caribeña, minando lentamente el imaginario de la élite de ciudad con cultura colonial, hispánica e intramuros, proyectándole el legado africano que ella alberga al Caribe insular. En este sentido el fenómeno es toda una revolución silenciosa , con una ideología difusa y no argumentada".

51. See WADE, Música, raza y nación; and HERNÁNDEZ Oscar, "Colonialidad y poscolonialidad musical en colombia", Latin American Music Review / Revista de música latinoamericana, vol. 28, no. 2, 2007, p. 242-270.

52. See GIRALDO Jorge and VEGA Jair, "Entre champeta y sonidos africanos: fronteras difusas y discusiones sobre 'músicas negras' en el Caribe colombiano”, Memorias, no. 23, 2014.

53. See "el tropipop" in SEVILLA et al., Travesías por la tierra del olvido.

54. See "Los creadores de la champeta" (youtube.com/watch?v=n-fc1ir2lAM, 07:55, accessed August 20, 2019). Louis Towers comments: "We, the elders, grew up listening to African music and we created champeta. If we enjoy this much with this kind of music, which is our essence, the least we expect is its transmission to our children. This joy our sons and daughters feel is precisely that essence we have passed them on" (my translation: "Nosotros, los mayores, crecimos escuchando la música africana, creamos la champeta. Y finalemente, si nosotros gozamos, disfrutamos tanto, con esta música que es nuestra esencia, lo mínimo que puede pasar es que eso pase a través de la sangre a nuestros hijos. El gusto tan profundo de la champeta en nuestros hijos, no es sino esa esencia que nosotros les heredamos"). 
55. For a discussion on safeguarding of Colombian ICH and its political articulations, see the record of the workshop "Políticas y planes para la salvaguardia del patrimonio cultural", organized by the Colombian Ministry of Culture and Crespial. Available at (crespial.org/public_files/files/Colombia.pdf, accessed May 14, 2019).

56. Aldana accurately draws a parallel between current repression and invisibility of black communities, and 'the common fear of the 'black menace' that terrorized plantation owners throughout the Caribbean in the nineteenth century" following the Haitian revolution. See ALDANA, "Policing culture", p. 274. Elías and Vidal ("La desmemoria") trace this fear back until the seventeenth century, when slaves and free Afro-descendants starkly outnumbered the white ruling class.

\section{ABSTRACTS}

The shifts and fractures introduced by UNESCO heritagisation processes, unleashed in the Colombian Caribbean from the early noughties, have been particularly acute when it comes to music practices. Eight out of ten Colombian practices inscribed on UNESCO's heritage lists are indeed either music-based or strongly music-related. This paper focuses on the ways in which champeta-an urban music-based identity crafted in the city of Cartagena from the mid-1980shas engaged in official and unofficial processes of heritagisation, in which practitioners have struggled to revise the locally contested and racialized burden borne by their cultural practice. Delving into the Afrocentric aims laid out by Afro-descendants and pioneers of champeta musicborn out of a Caribbean remake of "African" music styles such as soukous-this communitybased heritagisation process reveals itself as unsympathetic to hegemonic power formations, hence challenging those involved in the creation of heritage lists. This paper problematizes the relation between tangible and intangible heritage in Cartagena by assessing the impact of implementing safeguarding measures in tangible landmarks particularly enmeshed in colonial and slave history. It also explores how multiculturalism and heritage have become scenarios for political struggle in Colombia, hence shaping social and academic grounds for discussing issues such as cultural ownership, racial identification, musical genealogies and political upheaval.

Les déplacements et les fractures provoqués par les processus de patrimonialisation de l'UNESCO, qui ont affecté les Caraïbes colombiennes depuis le début des années 2000, ont été particulièrement sensibles dans le domaine des pratiques musicales. En effet, parmi les pratiques colombiennes inscrites sur les listes du patrimoine de l'UNESCO, huit sur dix sont fondées sur la musique ou fortement liées à la musique. Cet article porte sur la manière dont la champeta - une identité forgée autour de la musique urbaine de la ville de Cartagena à partir du milieu des années 1980 - a été prise dans des processus officiels ou non officiels de patrimonialisation, et sur les luttes engagées par ceux qui la pratiquent contre la charge sociale et l'absence de reconnaissance pesant sur leur pratique culturelle. En examinant les revendications afrocentriques des afrodescendants et des pionniers de la musique champeta - issue d'un remake caribéen de styles musicaux « africains » tels que le soukous -, on s'aperçoit que ce processus de patrimonialisation au fort ancrage communautaire résiste aux formes de pouvoir hégémoniques, et constitue un défi pour ceux qui œuvrent à la création des listes patrimoniales. Cet article problématise la relation entre patrimoine matériel et immatériel à Cartagena, en évaluant 
l'impact des mesures de sauvegarde des monuments matériels notoirement liés à l'histoire coloniale et esclavagiste. Il explore également la façon dont le multiculturalisme et le patrimoine sont devenus des scénarios de lutte politique en Colombie, où ils forment dès lors un terrain social et académique pour débattre de questions relatives à la propriété culturelle, à l'identification raciale, aux généalogies musicales et aux soulèvements politiques.

\section{INDEX}

Keywords: Caribbean studies, champeta, decolonialism, identity, intangible cultural heritage, multiculturalism.

Mots-clés: études caribéennes, champeta, décolonialisme, identité, patrimoine culturel immatériel, multiculturalisme

\section{AUTHOR}

\section{JUAN D. MONTOYA ALZATE}

Juan D. Montoya Alzate is a Colombian scholar and journalist whose main focus is bridging Caribbean-Colombian music-champeta, cumbia and bailes cantaos-with the fields of performance and heritage. He was appointed lead researcher for Medellin's application to join the UNESCO Creative Cities Network and conducted focused artistic research in Belgium, where stakeholders inscribed the carillon culture under the UNESCO list of Best Safeguarding Practices. He holds an MA in Cultural Studies (KU Leuven) and conducts research for the Amsterdam School for Cultural Analysis. He has been a regular collaborator of media outlets such as The New Herald (USA), Deutsche Welle (Germany), El Tiempo and El Espectador (Colombia). 